\title{
Caesarean section audit in a tertiary hospital of North India using Robson's classification
}

\author{
Ruchi Gupta* \\ Department of Obstetrics and Gynecology, Maulana Azad Medical College and Lok Nayak Hospital, Delhi, India
}

Received: 25 January 2019

Accepted: 05 March 2019

\section{*Correspondence:}

Dr. Ruchi Gupta,

E-mail: ruchiguptamgm@gmail.com

Copyright: () the author(s), publisher and licensee Medip Academy. This is an open-access article distributed under the terms of the Creative Commons Attribution Non-Commercial License, which permits unrestricted non-commercial use, distribution, and reproduction in any medium, provided the original work is properly cited.

\begin{abstract}
Background: In view of upsurging Caesarean section (CS) rate worldwide WHO conducted two multicountry surveys to diagnose the driving determinants. In two WHO surveys increased overall CS rate was observed from 26.4\% to 31.2\% worldwide except Japan. Both WHO 2014 and FIGO 2016 recommend Robson ten- group classification for monitoring caesarean rate over time because of its clarity, tenacity, resilience and pliability. Our Aim is to classify women delivered in our Hospital as per Robson ten -group classification and access the factor driving caesarean rate in each group.

Methods: This is a retrospective study 1671 caesarean section conducted in tertiary hospital over 6 months (JulyDecember) 2018. All the delivering women were classified according to Robson ten-group classification and data was analyzed using Microsoft excel and SPSS 23 software.

Results: During the study period there were 5917 deliveries. Of these 1671 deliveries were CS accounting for CS rate of $28.24 \%$. The major contributor to CS rate were women in group 5 followed by primigravida's in group 1 and 2 . Increasing CS rate was observed in group $1,2,3$ and 5. Most common indication for caesarean section was fetal distress, failed induction, previous caesarean , breech and Antepartum hemorrhage.

Conclusions: Increasing trend in CS rate is observed in group 1,2,3 and 5. In order to reduce CS rate among group 2 better patient selection is required for induction of labour based on Bishop score. In order to reduce CS rate in group 5 promotion of VBAC deliveries should be encouraged. By classifying women according to Robson group 10 classification helps in identification of women likely to deliver by caesarean and to identify effective strategies to optimize the CS rate.
\end{abstract}

Keywords: Bishop score, Caesarean section rate, Robson classification, VBAC

\section{INTRODUCTION}

Over the past few decades in view of increase in caesarean rate, WHO conducted two multicountry surveys to diagnose the driving determinants. WHO studies deliveries in 21 countries in both WHOGS [WHO global survey of Maternal and Perinatal health; 2004-08] and WHOMCS [WHO Multicountry Survey of Maternal and Newborn Health;2010-11]. Countries were stratified according to HDI [very high/high, medium, low]. Data utilized to establish AAPC [Average annual percentage change] in CS rate per country. Increased overall CS rate from $26.4 \%$ to $31.2 \%$ [p=0.003] in two WHO surveys in all countries except Japan [19.8\% to $18.6 \%$ ]. Use of obstetric interventions [induction, prelabour CS, and overall CS] also increased over time. ${ }^{1,2}$ In 2001 Robson proposed group ten classification system to investigate the difference in CS rates within these relatively 
homogenous groups of women. Authors are classifying women in our study according to Robson classification implementation manual released by WHO in 2017 to identify the women groups contributing maximally to overall CS rate and also implementing effective strategies to optimize CS rates. ${ }^{3}$ The Robson classifies women in 10 groups based on six obstetrics variables into 10 groups that are mutually exclusive and totally inclusive: ${ }^{3}$

- Parity- Nullipara/Multipara

- Previous CS- Yes/No

- Onset of labour: Spontaneous/Induced/No labour
- Number of foetuses: Singleton/Multiple

- Gestational age: Term (>37 weeks)/Preterm (<37 weeks)

- Fetal lie and presentation: Cephalic/Breech/ Transverse lie

Based on these obstetric variable women were classified into 10 groups as: ${ }^{3}$ Authors are classifying women according to group 10 and analyse the data as per Robson classification report table and comparing it with Multicountry Survey (MCS) reference population. ${ }^{3}$

Table 1: Robson 10-Group classification.

\begin{tabular}{|l|l|}
\hline Group & Women \\
\hline 1 & Nulliparous, single, cephalic, $>37$ weeks in spontaneous labour \\
\hline 3 & Nulliparous, single, cephalic, $>37$ weeks either induced or prelabour CS \\
\hline 4 & Multiparous, single, cephalic, $>37$ weeks in spontaneous labour \\
\hline 5 & Multiparous, single, cephalic, $>37$ weeks either induced or prelabour CS \\
\hline 6 & Previous CS, single, cephalic, $>37$ weeks \\
\hline 7 & Nulliparous breech \\
\hline 8 & Multiparous breech including previous CS \\
\hline 10 & Multiple pregnancies including previous CS \\
\hline & Transverse or oblique lie including previous CS \\
\hline
\end{tabular}

\section{METHODS}

This retrospective study was conducted in Maulana Azad Medical college and Lok Nayak Hospital, a tertiary teaching hospital in north india. All the women delivered during 6-month period from July 2018 to December 2018 were included in the study. The data were collected from institutional delivery and caesarean records from all Operation theatres and both clean and septic labour rooms. The data was collected and analyzed as per WHO implementation manual on Robsons classification using Microsoft excel and SPSS 23 software.

\section{Statistical analysis}

All the data was entered in Microsoft excel spreadsheet 2007 and was analyzed as per WHO implementation manual 2017 using SPSS statistics 23 for windows.

\section{RESULTS}

Total 5917 women were delivered during study period of which 1671 women delivered by caesarean section, accounting for caesarean rate of $28.24 \%$.

Table 2: Relative size of each group according to Robson 10-group classification.

\begin{tabular}{|l|l|l|}
\hline Robson groups & Relative size of each group (N=5917) & \% \\
\hline Nulliparous, single, cephalic, > 37 weeks in spontaneous labour & 1397 & 23.60 \\
\hline Nulliparous, single, cephalic, > 37 weeks either induced or prelabour CS & 537 & 9.07 \\
\hline Multiparous, single, cephalic, > 37 weeks in spontaneous labour & 1701 & 28.74 \\
\hline Multiparous, single, cephalic, > 37 weeks either induced or prelabour CS & 274 & 4.63 \\
\hline Previous CS, single, cephalic, > 37 weeks & 590 & 9.97 \\
\hline Nulliparous breech & 129 & 2.18 \\
\hline Multiparous breech including previous CS & 106 & 1.79 \\
\hline Multiple pregnancies including previous CS & 135 & 2.28 \\
\hline Transverse or oblique lie including previous CS & 24 & 0.40 \\
\hline Single, cephalic, $<37$ weeks including previous CS & 1024 & 17.30 \\
\hline
\end{tabular}


Table 3: CS rates in our hospital according to Robson 10-group classification.

\begin{tabular}{|c|c|c|c|c|c|}
\hline Group & No. of $\mathrm{CS}$ in group & $\begin{array}{l}\text { No. of } \\
\text { women in } \\
\text { group }\end{array}$ & Group CS rate (\%) & $\begin{array}{l}\text { Absolute } \\
\text { contribution to } \\
\text { overall CS rate (\%) }\end{array}$ & $\begin{array}{l}\text { Relative } \\
\text { contribution to } \\
\text { overall CS rate }(\%)\end{array}$ \\
\hline 1 & 240 & 1397 & 17.17 & 4.05 & 14.36 \\
\hline 2 & 257 & 537 & 47.85 & 4.34 & 15.38 \\
\hline 3 & 95 & 1701 & 5.58 & 1.60 & 5.68 \\
\hline 4 & 41 & 274 & 14.96 & 0.69 & 2.45 \\
\hline 5 & 508 & 590 & 86.10 & 8.58 & 30.40 \\
\hline 6 & 106 & 129 & 82.17 & 1.79 & 6.34 \\
\hline 7 & 52 & 106 & 49.05 & 0.87 & 3.11 \\
\hline 8 & 65 & 135 & 48.14 & 1.09 & 3.88 \\
\hline 9 & 24 & 24 & 100 & 0.40 & 1.43 \\
\hline 10 & 283 & 1024 & 27.63 & 4.78 & 16.93 \\
\hline
\end{tabular}

The data was analysed according to Robson classification, multigravida constitute the major group size of $33.3 \%(3+4)$ followed by nulligravidas constituting $32.6 \%(1+2)$. Women with previous caesarean with term pregnancy i.e. Group 5 constitutes third largest group of $9.97 \%$ women (Table 2). Group 5 was major contributor to CS rate accounting $86.1 \%$, followed by group 2 and 1 constituting $47.8 \%$ and $17.1 \%$ respectively. The CS rate among group 6-9 were more than $50 \%$. The relative contribution to overall CS rate by group 5, 1, and 2 was $30.40 \%, 14.36 \%$, and $15.38 \%$ respectively (Table 3 ).

The CS rate of our hospital was comparable to Robson guidelines as well as WHO MCS population except in Group 10, where increase CS rate was observed owing to increase in preterm section. (Table 4).

Table 4: Comparison of group size MAMC data with Robson standard WHO MCS population.

\begin{tabular}{|l|l|l|l|}
\hline $\begin{array}{l}\text { Group } \\
\text { sive }\end{array}$ & $\begin{array}{l}\text { MAMC } \\
(\%)\end{array}$ & $\begin{array}{l}\text { Robson } \\
\text { guideline }(\%)\end{array}$ & $\begin{array}{l}\text { MCS population } \\
(\%)\end{array}$ \\
\hline $1+2$ & 32.67 & $35-42$ & 38.1 \\
\hline $3+4$ & 33.67 & 30 & 46.5 \\
\hline 5 & 9.97 & $<10$ & 7.2 \\
\hline $6+7$ & 3.97 & $3-4$ & 2.7 \\
\hline 8 & 2.2 & $1.5-2$ & 0.9 \\
\hline 10 & 17.30 & $<5$ & 4.2 \\
\hline
\end{tabular}

Group size ratio in MAMC was comparable to Robson guidelines and WHO MCS population (Table 5). Increase CS rate was observed in MAMC group 1,2, and 5 as compare to Robson guideline and WHO MCS population (Table 6). Maximum caesarean were done for fetal distress i.e. $31.41 \%$ followed by Failed induction and Antepartum haemorrhage constituting $18.07 \%$ and $5.98 \%$ respectively. MCS reference population was the population with very good outcome in term of labour and childbirth with relatively low CS rate. The group size of group 1-8 in our hospital were comparable to Robson guideline and MCS population except in group 10 indicating increase in preterm caesarean section rate with better availability of nursery care.

Table 5: Comparison of group size ratio of MAMC with Robson guideline and MCS population.

\begin{tabular}{|l|l|l|l|}
\hline Group sive ratio & MAMC & $\begin{array}{l}\text { Robson } \\
\text { guideline }\end{array}$ & $\begin{array}{l}\text { MCS } \\
\text { population } \\
(\%)\end{array}$ \\
\hline Group 1/Group 2 & 2.60 & $>2: 1$ & 3.3 \\
\hline Group 3/Group 4 & 6.20 & $>2: 1$ & 6.3 \\
\hline Group 6/ Group7 & 1.2 & $>2: 1$ & 0.8 \\
\hline
\end{tabular}

Table 6: Comparison of CS rate in each group in MAMC v/s Robson guideline and WHO MCS population.

\begin{tabular}{|c|c|c|c|}
\hline $\begin{array}{l}\text { Group } \\
\text { CS rate } \\
(\%)\end{array}$ & MAMC (\%) & $\begin{array}{l}\text { Robson } \\
\text { guideline } \\
(\%)\end{array}$ & $\begin{array}{l}\text { MCS } \\
\text { population } \\
(\%)\end{array}$ \\
\hline Group 1 & 17.17 & $<10$ & 9.8 \\
\hline Group 2 & 47.85 & $20-35$ & 39.9 \\
\hline Group 3 & 5.58 & $<3$ & 3 \\
\hline Group 4 & 14.96 & $<15$ & 23.7 \\
\hline Group 5 & 86.1 & $50-60$ & 74.4 \\
\hline Group 8 & 48.14 & $<60$ & 57.7 \\
\hline Group 10 & 27.63 & $\approx 30$ & 25.1 \\
\hline
\end{tabular}

Table 7: Comparison of relative contribution of groups to overall CS rate in MAMC to Robson guideline and WHO MCS population.

\begin{tabular}{l|l|l|l|}
$\begin{array}{l}\text { Groups (relative } \\
\text { contribution to } \\
\text { overall CS rate } \\
\% \text { ) }\end{array}$ & MAMC & $\begin{array}{l}\text { Robson } \\
\text { guideline }\end{array}$ & $\begin{array}{l}\text { MCS } \\
\text { population }\end{array}$ \\
\hline $\begin{array}{l}\text { Group 1+2+5 } \\
\text { Group 5 }\end{array}$ & 60.14 & 66 & 63.7 \\
\hline
\end{tabular}


The group size ratio of various groups in our study were comparable to Robson guideline and MCS population indicating the similar distribution among various groups all over world in various countries. The CS rate in group 2 , 3, and 5 were greater in our study as compare to Robson guideline indicating greater number of caesareans among the women induced and also the women with previous caesarean. The group to be targeted to reduce $\mathrm{CS}$ rate were group 2 and 5. However in comparing overall CS rate the results of our study were comparable to Robson guideline and WHO MCS population (Table 7). Majority of caesarean were done for fetal distress constituting $31.41 \%$ followed by failed induction, breech and APH with $18.07 \%, 9.39 \%$, and $5.98 \%$ (Table 8).

Table 8: Indication for caesarean in MAMC.

\begin{tabular}{|l|l|l|}
\hline $\begin{array}{l}\text { Indication of caesarean } \\
\text { section }\end{array}$ & Number & $\%$ \\
\hline Fetal distress & 525 & 31.41 \\
\hline Failed induction & 302 & 18.07 \\
\hline APH & 100 & 5.98 \\
\hline Breech & 157 & 9.39 \\
\hline Twins/ triplet/quadruplet & $59 / 8 / 1$ & $3.5 / 0.47 / 0.05$ \\
\hline Transverse lie & 24 & 1.43 \\
\hline Previous cs 1/2/3 & $82 / 137 / 11$ & $4.90 / 8.19 / 0.65$ \\
\hline Scar tenderness & 78 & 4.66 \\
\hline $\begin{array}{l}\text { Cephalopelvic } \\
\text { disproportion }\end{array}$ & 77 & 4.60 \\
\hline Non-progress of labour & 40 & 2.39 \\
\hline $\begin{array}{l}\text { Cord prolapse } \\
\text { Obstructed labour }\end{array}$ & 7 & 0.41 \\
\hline $\begin{array}{l}\text { Antepartum eclampsia } \\
\text { with poor bishop }\end{array}$ & 2 & 0.41 \\
\hline IVF conceived & 27 & 0.11 \\
\hline $\begin{array}{l}\text { Elective caesarean in } \\
\text { women with medical } \\
\text { disorders }\end{array}$ & 7 & 1.61 \\
\hline $\begin{array}{l}\text { FGR with deranged } \\
\text { doppler }\end{array}$ & 20 & 0.41 \\
\hline Total & 1671 & 1.19 \\
\hline & & \\
\hline
\end{tabular}

\section{DISCUSSION}

The caesarean rate reported in our study i.e. $28.24 \%$, was higher that WHO recommendation of CS rate between $10 \%-15 \% .^{4}$ The results of our study was comparable to study done by Tapia $\mathrm{V}$ et al with reported CS rate of $27 \% .^{5}$ The CS rate of our study were consonant with study done by $\mathrm{P}$ Joushua et al , they reported an increase in caesarean rate from $26.4 \%$ to $31.2 \%$ between two WHO multicountry surveys. ${ }^{6}$ The CS rate of were hospital was lower than other tertiary hospital of Southern India as reported by Koteshwara et al and Prabhavati $\mathrm{V}$ et al, they reported a CS rate of $37.6 \%$ and $35.9 \% .^{7,8}$ In our study an increase in CS rate was observed in Group 1,2 and 5 which were similar to the study done by Emmanuelle Lesieur et al and Justina Kacerauskiene et al. ${ }^{9,10}$ The results were also comparable to study done by Koteshwara et al, where the major contributor to CS rate were group 1, 2, and $5 .{ }^{7}$ The groups 1,2 , and 5 contributes $60.10 \%$ of total CS rate, consubstantial with study done by DJ Brennan et al. ${ }^{11}$ In our study group 3 was the major contributor to vaginal delivery constituting $28.74 \%$ which was comparable to study done by Maria L Costa et al. ${ }^{12}$ Women in group 3 and group 1 were the two largest groups contributing to the deliveries similar to studies done by FP McCarthy et al. ${ }^{13}$ In Group 5, CS rate was $86.10 \%$ which was in accordance with other studies .11,14,15.Group size of group 5 and group 6 in our study was $9.97 \%$ and $2.18 \%$ which were relatable to study done by Kazmi T et al. ${ }^{16}$ The contribution to overall CS rate in all groups in our study were congruent with study done by Kazmi et al. ${ }^{16}$ Group 6-10 were smaller groups with very high CS rate, matching with study done by Kazmi et al. ${ }^{16}$ Most frequent indications for caesarean section in our study was fetal distress followed by failed induction, previous caesarean and breech. These results were in agreement to the study done by $\mathrm{J}$ Thomas et al. ${ }^{17}$

\section{CONCLUSION}

Auditing the data as per Robson's Ten group classification is a finer way to invigilate and compare the CS rate in a definitive and coherent manner. In our study an increase in CS rate was observed in group 1,2,3 and 5. In order to reduce CS rate among group 1 and 3, low risk patients should be allowed for spontaneous onset of labour till 41 weeks. For reducing CS rate in group 2, better patient selection is required for induction of labour based on Bishop score and for group 5 VBAC deliveries should be encouraged.

\section{Funding: No funding sources Conflict of interest: None declared \\ Ethical approval: The study was approved by the Institutional Ethics Committee}

\section{REFERENCES}

1. Souza JP, Gülmezoglu AM, Lumbiganon P, Laopaiboon M, Carroli G, Fawole B. Caesarean section without medical indications is associated with an increased risk of adverse short-term maternal outcomes: the 2004-2008 WHO Global Survey on Maternal and Perinatal Health. BMC Med. 2010;8(1):71.

2. Souza JP, Tuncalp O, Vogel JP, Bohren M, Widmer M, Oladapo OT et al. Obstetric transition: the pathway towards ending preventable maternal deaths. BJOG: An Int J Obstet Gynaecol. 2014;121(1):1-4.

3. WHO 2017, Robson classification: Implementation manual. Available http://creativecommons.org/licences/by-ncsa/3.0/igo.

4. WHO statement on caesarean section rates; WHO/RHR/15.02 
5. Tapia V, Betran AP, Gonzales GF. Caesarean Section in Peru: Analysis of Trends Using the Robson Classification System. PLoS One. 2016 PLoS One. 2016;11(2):e0148138.

6. Vogel JP, Betrán AP, Vindevoghel N, Souza JP, Torloni MR, Zhang $\mathrm{J}$ et al. Use of the Robson classification to assess caesarean section trends in 21 countries: a secondary analysis of two WHO multicountry surveys. Lancet Global Health. 2015;3(5):e260-70.

7. Koteshwara S, Sujatha MS. Analysis of caesarean section using Robsons ten group classification: the first step. Int $\mathbf{J}$ Reproduct Contracept Obstet Gynecol.2017;6(8):3481-5

8. Prabhavathi V, Krishnamma B, Prasad DKV, Bhavya K, Satyavathi R. Audit of caesarean deliveries in a tertiary care hospital of northern Andhra Pradesh using modified Robson criteria. Int J Reproduct Contracept Obstet Gynecol.2018;7(7):2796-2801.

9. Lesieur E, Blanc J, Loundou A, Claquin A, Marcot M, Heckenroth $\mathrm{H}$, Bretelle F. Teaching and performing audits on caesarean delivery reduce the caesarean delivery rate. PloS one. 2018;13(8):e0202475.

10. Kacerauskiene J, Bartuseviciene E, Railaite DR, Minkauskiene M, Bartusevicius A, Kliucinskas M. et al. Implementation of the Robson classification in clinical practice: Lithuania's experience. BMC Pregnancy Childbirth. 2017;17(1):432.

11. Brennan DJ, Robson MS, Murphy M, O'Herlihy C. Comparative analysis of international caesarean delivery rates using 10-group classification identifies significant variation in spontaneous labor. Am J Obstet Gynecol. 2009;201(308):e301-8

12. Costa ML, Cecatti JG, Souza JP, Milanez HM, Gülmezoglu MA. Using a Caesarean Section Classification System based on characteristics of the population as a way of monitoring obstetric practice. Reproduct Health. 2010;7(1):13.

13. McCarthy FP, Rigg L, Cady L, Cullinane F: A new way of looking at Caesarean section births. Aust N Z J Obstet Gynaecol. 2007, 47(4):316-20.

14. Harper LM, Macones GA: Predicting success and reducing the risks when attempting vaginal birth after cesarean. Obstet Gynecol Surv. 2008;63(8): 538-45.

15. Rossi AC, D'Addario V: Maternal morbidity following a trial of labor after cesarean section vs elective repeat cesarean delivery: a systematic review with metaanalysis. Am J Obstet Gynecol. 2008;199 (3):224-31.

16. Kazmi T, Saiseema S, Khan S. Analysis of Cesarean Section Rate - According to Robson's 10-group Classification. Oman Med J. 2012;27(5):415-7.

17. Thomas J, Paranjothy S. The national sentinel caesarean section audit report. National Sentinel Caesarean Section Audit Report. 2001.

Cite this article as: Gupta R. Caesarean section audit in a tertiary hospital of North India using Robson's classification. Int J Reprod Contracept Obstet Gynecol 2019;8:1426-30. 